\title{
Dynamics of intracellular calcium induced by lactate and glucose in rat pachytene spermatocytes and round spermatids
}

\author{
J. G. Reyes ${ }^{1,4}$, E. Herrera ${ }^{1}$, L. Lobos ${ }^{1}$, K. Salas², N. Lagos², \\ R. A. Jorquera ${ }^{3}$, P. Labarca ${ }^{3}$ and D. J. Benos ${ }^{4}$ \\ 1 Instituto de Quimica, Universidad Catolica de Valparaiso, Avda. Brasil 2950, Casilla 4059, \\ Valparaiso, Chile; ${ }^{2}$ Instituto de Ciencias Biomédicas, Facultad de Medicina, \\ Universidad de Chile, Santiago, Chile; ${ }^{3}$ Centro de Estudios Cientificos, Valdivia, Chile; and \\ ${ }^{4}$ Department of Physiology and Biophysics, The University of Alabama at Birmingham, \\ Birmingham, AL 35294, USA
}

\begin{abstract}
Glycolytic metabolism in meiotic and post-meiotic spermatogenic cells shows differentiation-related changes. The developmental and physiological significance of these metabolic changes is not known. The aim of the present study was to test the hypothesis that glucose and lactate metabolism can modulate intracellular calcium $\left[\mathrm{Ca}^{2+}\right]_{i}$ in spermatogenic cells in an opposing and dynamic manner. Fluorescent probes were used to measure $\left[\mathrm{Ca}^{2+}\right]_{\mathrm{i}}$ and $\mathrm{pH}_{\mathrm{i}}$, and HPLC was used to measure intracellular adenine nucleotides and mitochondrial sensing of ATP turnover. $\left[\mathrm{Ca}^{2+}\right]_{i}$ in pachytene spermatocytes and round spermatids was modulated by changes in lactate and glucose concentrations in the media. The kinetics and magnitude of the $\left[\mathrm{Ca}^{2+}\right]_{i}$ changes induced by lactate and glucose were different in meiotic and post-meiotic spermatogenic cells.
\end{abstract}

The presence of glucose in the medium induced a decrease in $\mathrm{pH}_{\mathrm{i}}$ in spermatogenic cells. This glucose-induced $\mathrm{pH}_{\mathrm{i}}$ decrease occurred later than the changes in $\left[\mathrm{Ca}^{2+}\right]_{\mathrm{i}}$, which were also observed when the $\mathrm{pH}_{\mathrm{i}}$ decrease was inhibited, indicating that the glucose-induced $\left[\mathrm{Ca}^{2+}\right]_{i}$ increase was not a consequence of $\mathrm{pH}_{\mathrm{i}}$ changes. Hexose phosphorylation in glycolysis was part of the mechanism by which glucose metabolism induced $a\left[\mathrm{Ca}^{2+}\right]_{i}$ increase in spermatogenic cells. The sensitivity of $\left[\mathrm{Ca}^{2+}\right]_{i}$ to carbohydrate metabolism was higher in round spermatids than in pachytene spermatocytes. Thus, differentiation-related changes in carbohydrate metabolism in spermatogenic cells determine a dynamic and differential modulation of their $\left[\mathrm{Ca}^{2+}\right]_{i}$ by glucose and lactate, two substrates secreted by the Sertoli cells.

\section{Introduction}

The functional relationships between germ and Sertoli cells in the seminiferous tubules may occur either through physical contact (adhesion molecules) or through molecules secreted into the extracellular space in the adluminal compartment (Jegou, 1993). The precise composition of the extracellular environment of germinal cells in the seminiferous tubules has not been determined. However, it is expected that lactate is secreted into this compartment by Sertoli cells as a product of glucose metabolism (Robinson and Fritz, 1981; Mita et al., 1982; Le Gac et al., 1983). The glycolytic activity of Sertoli cells is stimulated by FSH, $\beta$-adrenergic agonists, IL1- $\beta$ and tumour necrosis factor $\alpha$ (TNF- $\alpha$; Mita et al., 1982; Le Gac et al., 1983; Hall and Mita, 1984; Riera et al., 2001) and a similar regulation is expected of the lactate secretion rate toward the adluminal compartment.

Hexose transporters are present inside the seminiferous tubules (Angulo et al., 1998) and Sertoli cells can take up glucose from the external medium (Hall and Mita, 1984). Furthermore, a non-metabolizable analogue of glucose can

Email: jreyes@ucv.cl cross the blood-testis barrier (Turner et al., 1983), indicating that glucose can enter the adluminal compartment through Sertoli cells. The rate of glucose secretion by Sertoli cells toward the adluminal compartment is expected to vary inversely with the rate of metabolic glucose consumption by these cells.

Pachytene spermatocytes and round spermatids can take up glucose from their external medium (Nakamura et al., 1986) and metabolize this sugar through glycolytic and oxidative metabolism (for example, see Grootegoed et al., 1984). Carbohydrate metabolism of spermatogenic cells undergoes differentiation-related changes (Bajpai et al., 1998). This metabolic change determines that meiotic spermatogenic cells have a high glycolytic flux (Bajpai et al., 1998) and that round spermatids respond to glucose metabolism with a decrease in ATP content (Nakamura et al., 1982; Grotegoed et al., 1986). These differentiationrelated changes in glycolytic metabolism of spermatogenic cell have been perplexing in terms of their physiological implications. Herrera et al. (2000) reported that long-term incubation with glucose induced a differential increase in $\left[\mathrm{Ca}^{2+}\right]_{i}$ in round spermatids of rats. As glucose and lactate fluxes toward the adluminal compartment are expected to 
vary according to the FSH-, catecholamine- or cytokinemodulated glycolytic activity of Sertoli cells, in the present study the hypothesis that spermatogenic cells can rapidly translate extracellular lactate and glucose changes to a dynamic behaviour of $\left[\mathrm{Ca}^{2+}\right]_{\mathrm{i}}$, linking external substrate supply by Sertoli cells to intracellular signalling in spermatogenic cells was tested. In addition, some of the mechanisms by which glucose can induce changes in $\left[\mathrm{Ca}^{2+}\right]_{\mathrm{i}}$ in round spermatids and pachytene spermatocytes were investigated.

\section{Materials and Methods}

\section{Materials}

Fluo-3 and fura-2 acetoxymethyl esters were obtained from Molecular Probes (Eugene, OR). Glucose, sodium L-lactate, 3-O-methyl-D-glucopyranoside (OMG), 2-deoxy glucose (DOG), iodoacetate, ionomycin, the enzymes, salts and buffers were obtained from Sigma Chemicals Co. (St Louis, MO). Thapsigargin was obtained from Calbiochem (La Jolla, CA).

\section{Preparation of rat spermatogenic cells}

Rat spermatogenic cells were prepared from the testes of adult (50-70 days of age) Wistar rats as described by Romrell et al. (1976). Rats were housed with free access to food and water under a $12 \mathrm{~h}$ light:12 h dark photoperiod. The animals were exposed to $\mathrm{CO}_{2}$ for $45 \mathrm{~s}$ and then killed by cervical dislocation. A 95\% $\mathrm{O}_{2}$ and $5 \% \mathrm{CO}_{2}$ atmosphere was maintained throughout the tissue enzymatic digestion procedure. The pachytene spermatocyte (85 $\pm 5 \%$ purity) and round spermatid fractions (92 $\pm 4 \%$ purity) were identified both by their size and by the typical aspect of their nucleus stained with $\mathrm{H}_{33342}$ (Molecular Probes; Reyes et al., 1997). The round spermatid fraction contained cells between stages one and seven. Our method of vital cell identification did not allow a sub-classification of rat spermatids at these stages of development. The isolated cells were used within $4 \mathrm{~h}$ after the purification procedures.

\section{Intracellular $\mathrm{Ca}^{2+}$ measurements of spermatogenic cells in suspension}

Measurements of $\left[\mathrm{Ca}^{2+}\right]_{i}$ in pachytene spermatocytes and round spermatids in suspension were performed in cells loaded with fura-2. Cells were loaded with the dye by incubation of approximately $5 \times 10^{6}$ cells ml-1 with $5 \mu \mathrm{mol}$ acetoxymethyl fura-2 $\mathrm{I}^{-1}$ in a medium containing $140.0 \mathrm{mmol}$ $\mathrm{Na}^{+} \mathrm{I}^{-1}, 4.6 \mathrm{mmol} \mathrm{K} \mathrm{K}^{-1}, 1.6 \mathrm{mmol} \mathrm{Mg}^{2+} \mathrm{I}^{-1}, 1.6 \mathrm{mmol}$ phosphate $\mathrm{I}^{-1}, 0.5 \mathrm{mmol} \mathrm{Ca}^{2+} \mathrm{I}^{-1}, 10 \mathrm{mmol}$ Hepes $\mathrm{I}^{-1}$, $\mathrm{pH} 7.4(\mathrm{KH}), 24 \mathrm{mmol}$ bicarbonate $(\mathrm{KHB}) \mathrm{I}^{-1}$ and $5 \mathrm{mmol}$ L-lactate (KHB-lactate) $\mathrm{I}^{-1}$ for $1 \mathrm{~h}$ at room temperature and in an atmosphere of $95 \% \mathrm{O}_{2}$ and $5 \% \mathrm{CO}_{2}$. The cells were then washed three times in $\mathrm{KH}$ medium and maintained at $4^{\circ} \mathrm{C}$ until used. The measurements were performed in a Fluoromax-2 (Jobin Ivon-Spex, Edison, NJ) fluorometer using a ratiometric method as described by Grynkiewicz et al. (1985). Calibration of fura-2 was performed by lysis of the cells with digitonin $\left(20 \mu \mathrm{g} \mathrm{m}^{-1}\right)$ in medium that contained $0.5 \mathrm{mmol} \mathrm{Ca}^{2+} \mathrm{I}^{-1}\left(F_{\max }\right)$ and subsequent addition of a final concentration of 5 mmol EGTA I-1 $\left(\mathrm{pH} \mathrm{7.4)}\left(F_{\min }\right)\right.$. The $K_{d}$ value for fura-2/Ca ${ }^{2+}$ was $250 \mathrm{nmol} \mathrm{I-1}$ and was interpolated from the data in Larsson et al. (1999) at $33^{\circ} \mathrm{C}$. The addition of glucose and lactate to cells in different metabolic conditions was performed to examine the effects of these substrates on $\left[\mathrm{Ca}^{2+}\right]_{i}$ dynamics. The first condition was depletion of external substrates. This condition was reached by incubation of the cell suspension for $20 \mathrm{~min}$ at $33^{\circ} \mathrm{C}$ in the absence of external substrates and with abundant $\mathrm{O}_{2}$. This condition also allowed characterization of the ability of lactate to decrease $\left[\mathrm{Ca}^{2+}\right]_{\mathrm{i}}$ and to maintain a low steady-state of $\left[\mathrm{Ca}^{2+}\right]_{i}$ in the cells. The second condition was minimal lactate supply $\left(0.5 \mathrm{mmol}\right.$ L-lactate $\left.\mathrm{I}^{-1}\right)$. This condition allowed maintenance of low concentrations of $\left[\mathrm{Ca}^{2+}\right]_{i}$ and revealed the ability of glucose to increase $\left[\mathrm{Ca}^{2+}\right]_{i}$. All experiments performed in the nominal absence of external $\mathrm{Ca}^{2+}$ were made with $\mathrm{KH}$ medium without $\mathrm{Ca}^{2+}$,

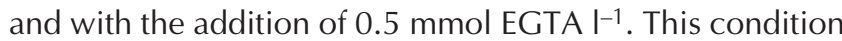
gives an estimated free $\mathrm{Ca}^{2+}$ concentration of approximately $3 \mathrm{nmol} \mathrm{I}^{-1}$. Control measurements for possible quenching or enhancement of fura-2/Ca $\mathrm{Ca}^{2+}$ fluorescence by glucose, L-lactate, DOG, OMG (5 mmol $\mathrm{I}^{-1}$ each) or $1 \mathrm{mmol}$ iodoacetate $\mathrm{I}^{-1}$ were performed with $0.5 \mu \mathrm{mol}$ fura- $2 \mathrm{I}^{-1}$ and 20 or $100 \mathrm{nmol}$ free $\mathrm{Ca}^{2+} \mathrm{I}^{-1}$. In each case, the different substances induced changes in fluorescence equivalent to $<3$ nmol free $\mathrm{Ca}^{2+} \mathrm{I}^{-1}$ changes in the cells.

\section{Measurements of $\left[\mathrm{Ca}^{2+}\right]_{i}$ in single cells}

The variations of $\left[\mathrm{Ca}^{2+}\right]_{i}$ in single cells were estimated using the fluorescent probe fluo-3 (excitation wavelengths 450-490 nm, emission wavelengths > $510 \mathrm{~nm}$ ). Acetoxy-

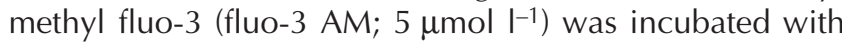
the cells for $30 \mathrm{~min}$ at room temperature $\left(18 \pm 2^{\circ} \mathrm{C}\right)$. The cells were allowed to settle on the glass coverslip bottom of a microscope chamber $(0.7 \mathrm{ml})$ on a temperature-regulated microscope stage at $33^{\circ} \mathrm{C}$ for $10 \mathrm{~min}$ and were then washed with $\mathrm{KH}$-lactate buffer. The medium surrounding the cells in the microscope chamber was changed by perfusing $10 \mathrm{ml}$ of the corresponding solution using a peristaltic pump at a rate of approximately $3 \mathrm{ml} \mathrm{min}{ }^{-1}$. The cell fluorescence was quantified using videomicroscopy in an inverted Nikon Diaphot microscope with epifluorescence and $\mathrm{a} \times 40$ fluo objective (NA 0.85). A cooled CCD, 12-bit videocamera (Spectrasource, Los Angeles, CA) was attached to the videoport of the microscope. The image analysis was performed with appropriate software using a personal computer. Background fluorescence, standardized for the appropriate window size, was taken from a zone in the image without cells and subtracted from the fluorescence in each cell.

\section{Oxygen consumption measurements}

Oxygen consumption $\left(\mathrm{QO}_{2}\right)$ measurements were performed using a Clark type $\mathrm{O}_{2}$ sensing electrode (YSI, Yellow 

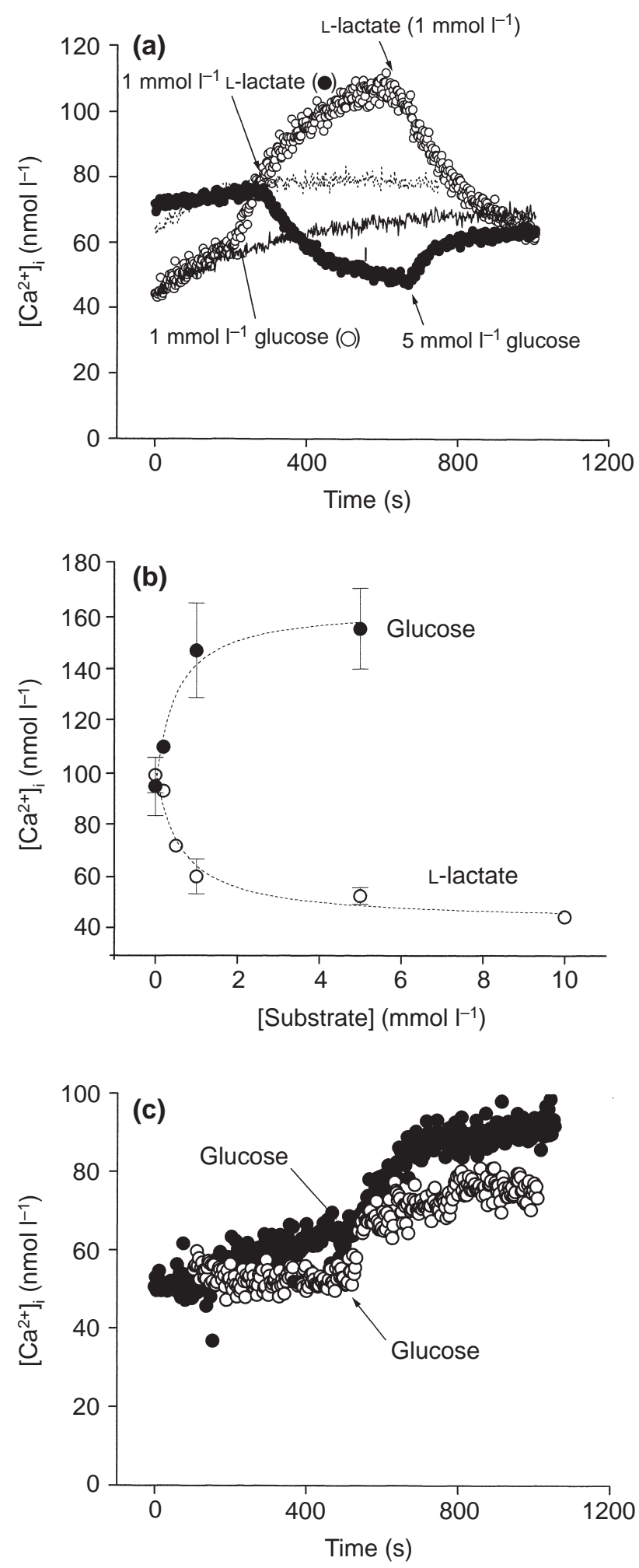

Fig. 1. (a) Intracellular $\left[\mathrm{Ca}^{2+}\right]$ of round spermatids loaded with fura-2 in rats. The measurements were made in a spectrofluorometer at $33^{\circ} \mathrm{C}$ in $\left.140.0 \mathrm{mmol} \mathrm{Na}^{+}\right|^{-1},\left.4.6 \mathrm{mmol} \mathrm{K}^{+}\right|^{-1}, 1.6 \mathrm{mmol}$ $\mathrm{Mg}^{2+} \mathrm{I}^{-1}, 1.6 \mathrm{mmol}$ phosphate $\mathrm{I}^{-1}, 0.5 \mathrm{mmol} \mathrm{Ca}{ }^{2+} \mathrm{I}^{-1}, 10 \mathrm{mmol}$ Hepes $\mathrm{I}^{-1}, \mathrm{pH} 7.4(\mathrm{KH})$ buffer. The cells were incubated previously

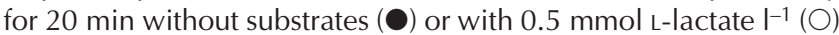

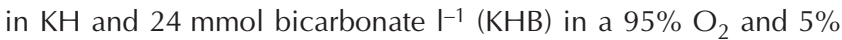

Springs, $\mathrm{OH})$ in a sealed glass chamber $(0.9 \mathrm{ml})$ surrounded by a water jacket kept at $33^{\circ} \mathrm{C}$. Isolated spermatogenic cells were pre-incubated for $1 \mathrm{~min}$ in $\mathrm{KH}$ buffer at $33^{\circ} \mathrm{C}$ before being transferred to the $Q_{2}$ chamber. $Q \mathrm{O}_{2}$ values were obtained from the slope of the $\mathrm{O}_{2}$ tension versus time curve between 0.5 and 2.0 min after each experimental addition of substrate.

\section{Determination of the intracellular adenine nucleotide content of rat round spermatids}

Rat round spermatids in suspension were incubated at a concentration of approximately $6 \mathrm{mg}$ cell protein $\mathrm{ml}^{-1}$ in $\mathrm{KHB}-$ lactate at $33^{\circ} \mathrm{C}$ and under an atmosphere of $95 \% \mathrm{O}_{2}$ and $5 \% \mathrm{CO}_{2}$ for $10 \mathrm{~min}$. Subsequently, the cells were washed in $\mathrm{KH}$ buffer and subjected to different conditions for several time periods. After the reported incubation times, $400 \mu \mathrm{l}$ of the cell sample was added to an ice-cold microcentrifuge tube and pelleted by centrifugation at $16000 \mathrm{~g}$ for $30 \mathrm{~s}$. The supernatant was then removed and the pellet was processed as described by Herrera et al. (2000). A procedure and storage control was made by taking duplicate $200 \mu \mathrm{l}$ samples of $2 \mathrm{mmol}$ ATP and ADP solutions $\mathrm{I}^{-1}$ and subjecting them to the previously mentioned sample processing and storage conditions. The samples were maintained at $-20^{\circ} \mathrm{C}$ until they were thawed and analysed by an HPLC equipped with high-pressure pumps coupled to an automated gradient controller, UCK injector and UV detector (model 501; Millipore, Waters). Nucleotide separation was obtained with an anion exchange column (MA7Q, $50.0 \times 7.8 \mathrm{~mm}$; BioRad) at a flow of $1.5 \mathrm{ml} \mathrm{min}^{-1}$ and at room temperature. The mobile phases were $0.01 \mathrm{~mol}$ MOPS I-1 $+0.01 \mathrm{~mol} \mathrm{KCl} \mathrm{I-1}^{-1}, \mathrm{pH} 7.0$ and $0.1 \mathrm{~mol} \mathrm{MOPS} \mathrm{I}^{-1}$ $+0.5 \mathrm{~mol} \mathrm{KCl} \mathrm{I}^{-1}, \mathrm{pH}$ 7.0. Calibration was performed with diluted standards of ATP, ADP and AMP $\left(2 \mathrm{mmol} \mathrm{I}^{-1}\right)$.

$\mathrm{CO}_{2}$ atmosphere. At the indicated times (arrows), different concentrations of glucose or L-lactate were added. The dotted or continuous trace corresponds to controls without or with $0.5 \mathrm{mmol}$ L-lactate $\mathrm{I}^{-1}$, respectively. The effect of the addition of glucose and lactate on intracellular $\left[\mathrm{Ca}^{2+}\right]$ was similar in at least 15 different cell preparations. (b) Steady-state intracellular $\left[\mathrm{Ca}^{2+}\right]$ of rat round spermatids loaded with fura-2. The measurements were made in a spectrofluorometer at $33^{\circ} \mathrm{C}$ in $\mathrm{KH}$. The cells were incubated previously for 20 min without substrates in $\mathrm{KHB}$ buffer in a $95 \% \mathrm{O}_{2}$ and $5 \% \mathrm{CO}_{2}$ atmosphere. L-lactate $(\bigcirc)$ or glucose $(-)$ was added at the indicated concentrations and $\left[\mathrm{Ca}^{2+}\right]_{i}$ was monitored for $15 \mathrm{~min}$ until a steady-state value was obtained. The measurements shown were obtained from five or more cell preparations. (c) Intracellular $\left[\mathrm{Ca}^{2+}\right]$ of round spermatids in rats loaded with fura- 2 . The measurements were made in a spectrofluorometer at $33^{\circ} \mathrm{C}$ in $\mathrm{KH}$ buffer supplemented with $0.5 \mathrm{mmol}$ EGTA $\mathrm{I}^{-1}$. The cells were incubated previously for $10 \mathrm{~min}$ with $0.5 \mathrm{mmol}$ L-lactate $\mathrm{I}^{-1}$ and the measurements were performed in the absence $(\bigcirc)$ and presence $(\bullet)$ of $0.5 \mathrm{mmol}$ external free $\mathrm{Ca}^{2+} \mathrm{I}^{-1}$. At the indicated times (arrows), 5 mmol glucose $\mathrm{I}^{-1}$ was added. This behaviour of intracellular $\left[\mathrm{Ca}^{2+}\right]$ in response to the addition of glucose was similar in at least three different cell preparations. 


\section{Intracellular pH measurements}

Intracellular $\mathrm{pH}$ of round spermatids was determined using the fluorescent probe 2',7'-bis-(2-carboxyethyl-5(and -6)-carboxyfluorescein (BCECF). The cells in suspension were incubated in $\mathrm{KHB}$-lactate in an atmosphere of $95 \% \mathrm{O}_{2}$ and $5 \% \mathrm{CO}_{2}$ with $0.5 \mu \mathrm{mol}$ BCECF-AM I-1 for $30 \mathrm{~min}$ at room temperature $\left(20 \pm 2^{\circ} \mathrm{C}\right)$ and subsequently washed in $\mathrm{KH}$ medium three times. Intracellular $\mathrm{pH}$ measurements were performed at a cell density of approximately $2 \times 10^{6}$ cells $\mathrm{ml}^{-1}$ in the appropriate solution. Calibration of intracellular BCECF was performed as described by Rink et al. (1982).

\section{Statistical analysis}

The data were analysed by $t$ tests. Where indicated, a paired $t$ test was performed to document relative differences in a variable. Non-linear regression was performed with the ORIGIN ${ }^{\mathrm{TM}}$ software package. The values reported are mean \pm SD unless stated otherwise.

\section{Results}

Kinetics and steady-state effects of glucose and lactate on $\left[\mathrm{Ca}^{2+}\right]_{i}$ in rat round spermatids and pachytene spermatocytes of rats

Round spermatids. The absence of exogenous substrates in round spermatids produced a steady increase in $\left[\mathrm{Ca}^{2+}\right]_{i}$ in the absence and presence of external $\mathrm{Ca}^{2+}$. The addition of L-lactate prevented this increase in $\left[\mathrm{Ca}^{2+}\right]_{i}$ in round spermatids. Thus, round spermatids incubated with $0.5 \mathrm{mmol}$ L-lactate $\mathrm{I}^{-1}$ in $\mathrm{KH}$ buffer had relatively low $\left[\mathrm{Ca}^{2+}\right]_{\mathrm{i}}$ $\left(53 \pm 11 \mathrm{nmol} \mathrm{I}^{-1}, n=30\right)$ and gained $\left[\mathrm{Ca}^{2+}\right]_{\mathrm{i}}$ at a rate of $3.5 \pm 2.5 \mathrm{nmol} \mathrm{min}{ }^{-1}(n=30)$. The addition of glucose to these cells produced an increase in $\left[\mathrm{Ca}^{2+}\right]_{i}$ (Fig. 1a) until a higher steady-state value was attained. Addition of L-lactate $\left(1 \mathrm{mmol} \mathrm{I}^{-1}\right)$ counteracted the effect of glucose (Fig. 1a). In cells incubated previously in the absence of external substrates, the addition of lactate lowered $\left[\mathrm{Ca}^{2+}\right]_{i}$ and subsequent addition of glucose produced an increase in $\left[\mathrm{Ca}^{2+}\right]_{i}$ to a new steady-state value (Fig. 1a). The glucose-induced increase in $\left[\mathrm{Ca}^{2+}\right]_{i}$ was dependent on the glucose concentration in the media with a $K_{0.5}$ value of $0.7 \mathrm{mmol} \mathrm{I}^{-1}$ (Fig. 1b). In the absence of other metabolic substrates, the presence of lactate produced a decrease in $\left[\mathrm{Ca}^{2+}\right]_{i}$ with a $K_{0.5}$ value of $0.89 \pm 0.25 \mathrm{mmol} \mathrm{I}^{-1}$ (Fig. 1b). The effect of the addition of glucose (at $0.5 \mathrm{mmol} \mathrm{I}^{-1}$ external L-lactate) on $\left[\mathrm{Ca}^{2+}\right]_{i}$ was similar in the presence $\left(0.5 \mathrm{mmol} \mathrm{I}^{-1}\right)$ and absence $\left(3 \mathrm{nmol} \mathrm{I}^{-1}\right)$ of external $\mathrm{Ca}^{2+}(55 \pm 13$ and $46 \pm 15 \mathrm{nmol} \mathrm{I}^{-1}$, respectively, $n=6$; Fig. 1c). In the absence of external $\mathrm{Ca}^{2+}$, the interpretation of the data was more directly linked to glucose-induced changes in intracellular $\mathrm{Ca}^{2+}$ homeostatic mechanisms. Thus, unless stated otherwise, the experiments described below were performed in the absence of external $\mathrm{Ca}^{2+}$. The effects of glucose on $\left[\mathrm{Ca}^{2+}\right]_{i}$ were less marked at higher lactate concentra-

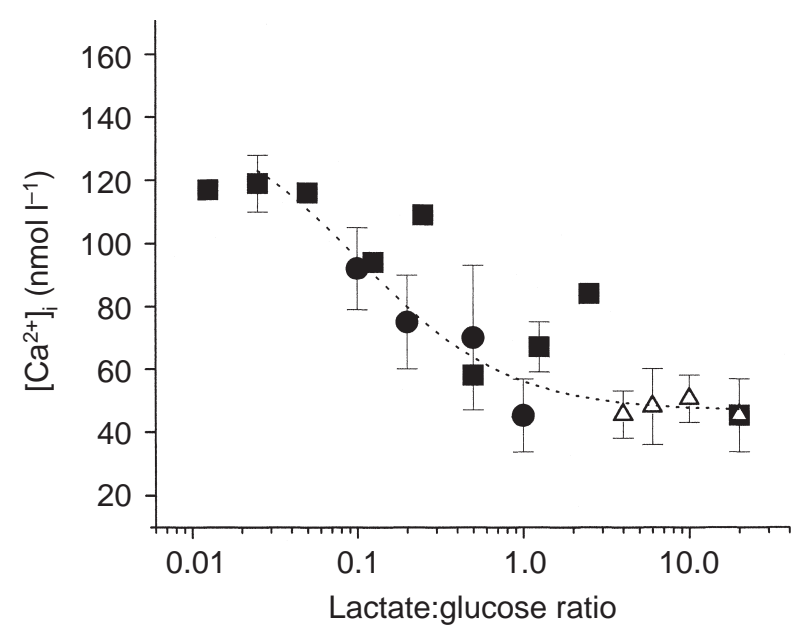

Fig. 2. Steady-state intracellular $\left[\mathrm{Ca}^{2+}\right]$ of round spermatids in rats as a function of the lactate: glucose ratio in the incubation medium. The cells were incubated previously in $140.0 \mathrm{mmol} \mathrm{Na}^{+} \mathrm{I}^{-1}$, $4.6 \mathrm{mmol} \mathrm{K} \mathrm{K}^{-1}, 1.6 \mathrm{mmol} \mathrm{Mg}^{2+} \mathrm{I}^{-1}, 1.6 \mathrm{mmol}$ phosphate $\mathrm{I}^{-1}$, $0.5 \mathrm{mmol} \mathrm{Ca}{ }^{2+} \mathrm{I}^{-1}, 10 \mathrm{mmol}$ Hepes $\mathrm{I}^{-1}, \mathrm{pH} 7.4(\mathrm{KH}), 24 \mathrm{mmol}$ bicarbonate (KHB) $\mathrm{I}^{-1}$ and $5 \mathrm{mmol}$-lactate (KHB-lactate) at $33^{\circ} \mathrm{C}$ in a $95 \% \mathrm{O}_{2}$ and $5 \% \mathrm{CO}_{2}$ atmosphere, washed three times in $\mathrm{KH}$

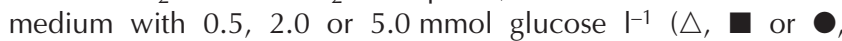
respectively) and added to the fluorometer cuvette. After a steady state of intracellular $\left[\mathrm{Ca}^{2+}\right]$ was obtained, lactate $(0.2-10.0 \mathrm{mmol}$ $\mathrm{I}^{-1}$ ) was added to reach the different ratios studied, and a new steady-state of intracellular $\left[\mathrm{Ca}^{2+}\right]$ was reached. The dotted line represents a sigmoidal curve and was drawn for reference purposes. The measurements shown were obtained from at least 12 different cell preparations.

tions. Thus, glucose $\left(5 \mathrm{mmol}^{-1}\right)$ induced changes of $46 \pm 15 \mathrm{nmol} \mathrm{I}^{-1}(n=6)$ in $\left[\mathrm{Ca}^{2+}\right]_{\mathrm{i}}$ at $0.5 \mathrm{mmol}$ L-lactate $\mathrm{I}^{-1}$ but induced changes in $\left[\mathrm{Ca}^{2+}\right]_{\mathrm{i}}$ of $21 \pm 10 \mathrm{nmol} \mathrm{I}^{-1}(n=6)$ at $1 \mathrm{mmol}$ L-lactate $\mathrm{I}^{-1}$. Thus, $\left[\mathrm{Ca}^{2+}\right]_{\mathrm{i}}$ appears to respond to the ratios of glycolytic and oxidative metabolism in postmeiotic spermatogenic cells. The steady-state of $\left[\mathrm{Ca}^{2+}\right]_{i}$ correlated in a non-linear manner with the external lactate:glucose ratio, and values of $\left[\mathrm{Ca}^{2+}\right]_{\mathrm{i}}$ ranged between approximately 120 and $40 \mathrm{nmol} \mathrm{I}^{-1}$ (Fig. 2).

Pachytene spermatocytes. When pachytene spermatocytes were incubated in $0.5 \mathrm{mmol}$ L-lactate $\mathrm{I}^{-1}$, they had relatively low $\left[\mathrm{Ca}^{2+}\right]_{\mathrm{i}}\left(41 \pm 8 \mathrm{mmol} \mathrm{I}^{-1}, n=15\right)$ and gained $\left[\mathrm{Ca}^{2+}\right]_{\mathrm{i}}$ at a rate of approximately $1.8 \pm 1.5 \mathrm{nmol} \mathrm{\textrm {min } ^ { - 1 }}$ $(n=15)$. The addition of glucose to these cells produced an increase in $\left[\mathrm{Ca}^{2+}\right]_{i}$ (Fig. 3) that was smaller than that in round spermatids. The addition of $1 \mathrm{mmol}$ L-lactate $\mathrm{I}^{-1}$ after the addition of glucose induced a rapid decrease in $\left[\mathrm{Ca}^{2+}\right]_{\mathrm{i}}$ similar to that observed before the addition of glucose. The

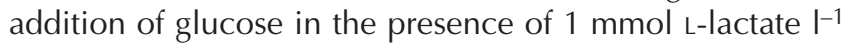
produced only a small increase in $\left[\mathrm{Ca}^{2+}\right]_{\mathrm{i}}(2.5 \pm 1.2 \mathrm{nmol}$ $\left.I^{-1}, n=6\right)$. In the absence of metabolic substrates, L-lactate produced a decrease in $\left[\mathrm{Ca}^{2+}\right]_{i}$ in pachytene spermatocytes with a $K_{0.5}$ value of $1.25 \pm 0.42 \mathrm{mmol} \mathrm{I}^{-1}$. At $0.5 \mathrm{mmol}$ L-lactate $\mathrm{I}^{-1}$, addition of $5 \mathrm{mmol}$ glucose $\mathrm{I}^{-1}$ produced a 


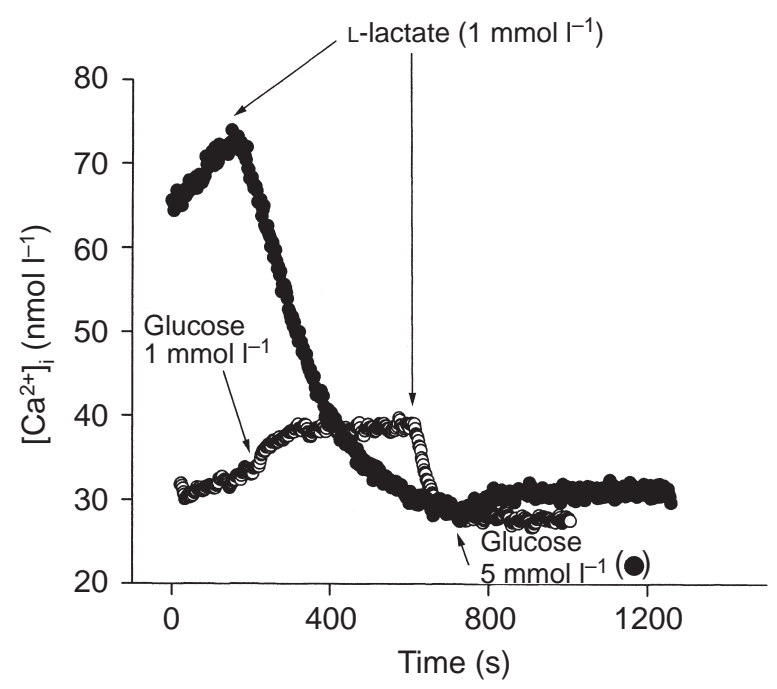

Fig. 3. Intracellular $\left[\mathrm{Ca}^{2+}\right]$ of pachytene spermatocytes loaded with fura- 2 in rats. The measurements were made in a spectrofluorometer at $33^{\circ} \mathrm{C}$ in $140.0 \mathrm{mmol} \mathrm{Na}^{+} \mathrm{I}^{-1}, 4.6 \mathrm{mmol} \mathrm{K} \mathrm{K}^{-1}$, $1.6 \mathrm{mmol} \mathrm{Mg}{ }^{2+} \mathrm{I}^{-1}, 1.6 \mathrm{mmol}$ phosphate $\mathrm{I}^{-1}, 0.5 \mathrm{mmol} \mathrm{Ca}^{2+} \mathrm{I}^{-1}$, $10 \mathrm{mmol}$ Hepes $\mathrm{I}^{-1}, \mathrm{pH} 7.4(\mathrm{KH})$ buffer. The cells were incubated previously for $20 \mathrm{~min}$ in $\mathrm{KH}$ and $24 \mathrm{mmol}$ bicarbonate $\mathrm{I}^{-1}$ (KHB) either without substrates $(0)$ or with $0.5 \mathrm{mmol}^{-}$lactate $\mathrm{I}^{-1}(\mathrm{O})$ in a $95 \% \mathrm{O}_{2}$ and $5 \% \mathrm{CO}_{2}$ atmosphere. At the indicated times (arrows), different concentrations of glucose or L-lactate were added. The effect of the addition of glucose and lactate on intracellular $\left[\mathrm{Ca}^{2+}\right]$ was similar in at least 15 different cell preparations.

significantly smaller change in $\left[\mathrm{Ca}^{2+}\right]_{\mathrm{i}}(19 \pm 8, n=7)$ in pachytene spermatocytes than in round spermatids $(P<0.05$ in a paired $t$ test). Furthermore, pachytene spermatocytes showed a transient response to glucose in contrast to the high steady-state values of $\left[\mathrm{Ca}^{2+}\right]_{i}$ reached in round spermatids (Fig. 4a). Thus, a differential response of $\left[\mathrm{Ca}^{2+}\right]_{i}$ to glucose was observed in round spermatids compared with pachytene spermatocytes.

\section{Effects of glucose on intracellular $\mathrm{Ca}^{2+}$ homeostasis in round spermatids}

Similar to other mammalian cells, $\left[\mathrm{Ca}^{2+}\right]_{i}$ in round spermatid and pachytene spermatocytes of rats was actively regulated by sarco-endoplasmic reticulum and plasma membrane $\mathrm{Ca}^{2+}$-ATPases. In these cells, intracellular $\mathrm{Ca}^{2+}$ stores seemed to be either permanently leaking $\mathrm{Ca}^{2+}$ or the $\mathrm{Ca}^{2+}$ exit pathways in intracellular $\mathrm{Ca}^{2+}$ stores were rapidly activated when sarco-endoplasmic reticulum ATPase activity was decreased (Berrios et al., 1998; Treviño et al., 1998; Herrera et al., 2000). The lack of a significant difference between the glucose-induced increase in $\left[\mathrm{Ca}^{2+}\right]_{i}$ in the presence and absence of external $\mathrm{Ca}^{2+}$ strongly indicates that most of the cytosolic $\left[\mathrm{Ca}^{2+}\right]$ increase induced by glucose came from intracellular $\mathrm{Ca}^{2+}$ stores. The following experiments were designed to determine the source of intracellular $\mathrm{Ca}^{2+}$ responsible for the glucose-induced changes in $\left[\mathrm{Ca}^{2+}\right]_{i}$ in round spermatids. In the absence or
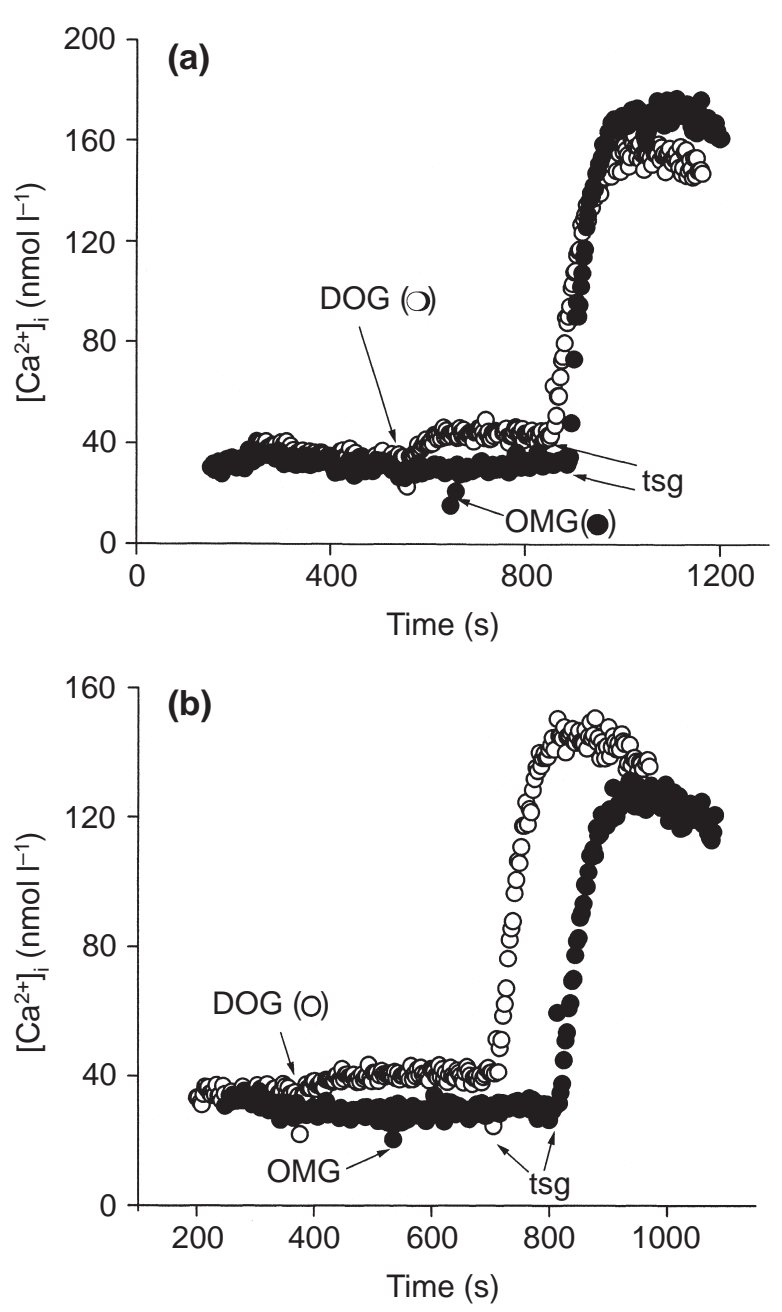

Fig. 4. Intracellular $\left[\mathrm{Ca}^{2+}\right]$ of rat (a) round spermatids and (b) pachytene spermatocytes loaded with fura-2. The measurements were made in a spectrofluorometer at $33^{\circ} \mathrm{C}$ in $140.0 \mathrm{mmol} \mathrm{Na}{ }^{-1}$, $4.6 \mathrm{mmol} \mathrm{K}^{+} \mathrm{I}^{-1}, 1.6 \mathrm{mmol} \mathrm{Mg}^{2+} \mathrm{I}^{-1}, 1.6 \mathrm{mmol}$ phosphate $\mathrm{I}^{-1}$, $0.5 \mathrm{mmol} \mathrm{Ca}{ }^{2+} \mathrm{I}^{-1}, 10 \mathrm{mmol}$ Hepes $\mathrm{I}^{-1}, \mathrm{pH} 7.4(\mathrm{KH})$ buffer. The cells were incubated previously for $20 \mathrm{~min}$ in $\mathrm{KH}, 24 \mathrm{mmol}$ bicarbonate $\mathrm{I}^{-1}$ (KHB) and $5 \mathrm{mmol}$ L-lactate (KHB-lactate) in a $95 \% \mathrm{O}_{2}$ and $5 \% \mathrm{CO}_{2}$ atmosphere, washed in $\mathrm{KH}$ medium and added to the fluorometer cuvette. At the indicated times (arrows), $5 \mathrm{mmol}$ 2-deoxyglucose (DOG, O) $\mathrm{I}^{-1}$ or $5 \mathrm{mmol}$ 3-O-methyl D-glucopyranoside (OMG, O) $\mathrm{I}^{-1}$ was added. Thapsigargin (tsg, $500 \mathrm{nmol} \mathrm{I}^{-1}$ ) was added to release intracellular $\mathrm{Ca}^{2+}$ stores. These measurements were representative of experiments performed in three different cell preparations.

presence of external $\mathrm{Ca}^{2+}$, intracellular $\mathrm{Ca}^{2+}$ stores were released with thapsigargin and the transient $\left[\mathrm{Ca}^{2+}\right]_{i}$ increase was allowed to subside towards a new steady-state. At this point (complete release of thapsigargin-sensitive intracellular $\mathrm{Ca}^{2+}$ stores), glucose was added (Fig. 5). The addition of glucose did not produce a further increase in $\left[\mathrm{Ca}^{2+}\right]_{i}$ $(n=4)$ in the presence or absence of external $\mathrm{Ca}^{2+}$. Furthermore, the subsequent addition of ionomycin induced the 


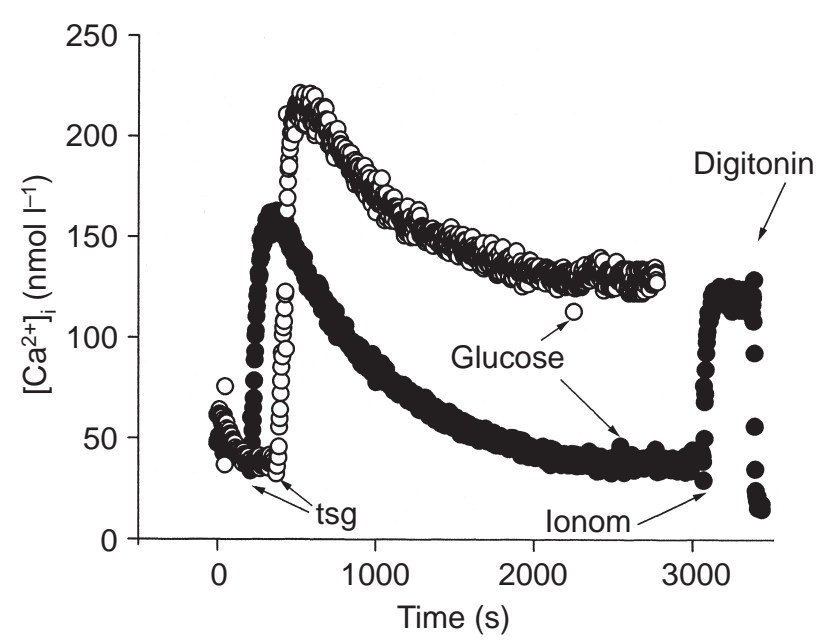

Fig. 5. Intracellular $\left[\mathrm{Ca}^{2+}\right]$ of round spermatids of rats loaded with fura- 2 in rats. The measurements were made in a spectrofluorometer at $33^{\circ} \mathrm{C}$ in $\left.140.0 \mathrm{mmol} \mathrm{Na}\right|^{-1},\left.4.6 \mathrm{mmol} \mathrm{K}^{+}\right|^{-1}, 1.6 \mathrm{mmol}$ $\mathrm{Mg}^{2+} \mathrm{I}^{-1}, 1.6 \mathrm{mmol}$ phosphate $\mathrm{I}^{-1}, 0.5 \mathrm{mmol} \mathrm{Ca}{ }^{2+} \mathrm{I}^{-1}, 10 \mathrm{mmol}$ Hepes $\mathrm{I}^{-1}, \mathrm{pH} 7.4(\mathrm{KH})$ buffer. The cells were washed and maintained in $\mathrm{KH}$ with $0.5 \mathrm{mmol}$ EGTA $\mathrm{I}^{-1}$. The cells were either without $(\bigcirc)$ or with $(\bigcirc) 1 \mathrm{mmol}$ external $\mathrm{Ca}^{2+} \mathrm{I}^{-1}$, giving approximate extracellular free $\mathrm{Ca}^{2+}$ concentrations of $3 \mathrm{nmol} \mathrm{I}^{-1}$ and $0.5 \mathrm{mmol} \mathrm{I}^{-1}$, respectively. L-lactate $\left(0.5 \mathrm{mmol} \mathrm{I}^{-1}\right)$ was added at zero time. Thapsigargin (tsg, $500 \mathrm{nmol} \mathrm{I}^{-1}$ ) was added to release intracellular $\mathrm{Ca}^{2+}$ stores. Glucose $\left(5 \mathrm{mmol} \mathrm{I}^{-1}\right)$ was added at the indicated times (arrows). lonomycin (lonom; $1 \mu \mathrm{g} \mathrm{ml}{ }^{-1}$ ) was added to release intracellular $\mathrm{Ca}^{2+}$ stores not released by tsg. Digitonin $\left(15 \mu \mathrm{g} \mathrm{m}^{-1}\right)$ was added to release fura-2 from the cytoplasm of the cells. These measurements were representative of experiments performed in three different cell preparations.

release of thapsigargin-insensitive $\mathrm{Ca}^{2+}$ stores present in these cells (for an example, see Pizzo et al., 1997; Berrios et al., 1998), indicating that thapsigargin-insensitive intracellular $\mathrm{Ca}^{2+}$ stores had a supply of $\mathrm{Ca}^{2+}$ susceptible to release if their $\mathrm{Ca}^{2+}$ permeability was increased, as shown with ionomycin. These measurements were terminated with digitonin, the addition of which permeabilized the cell plasma membrane and allowed confirmation that the $\left[\mathrm{Ca}^{2+}\right]_{i}$ increase induced by thapsigargin or ionomycin was not a consequence of $\mathrm{Ca}^{2+}$ entry. These results indicate that glucose induced the release of $\mathrm{Ca}^{2+}$ exclusively from thapsigargin-sensitive intracellular $\mathrm{Ca}^{2+}$ stores in rat round spermatids, rather than through activation of $\mathrm{Ca}^{2+}$ entry from the extracellular space or release of $\mathrm{Ca}^{2+}$ from thapsigargin-insensitive intracellular $\mathrm{Ca}^{2+}$ stores.

The glucose-induced increase in $\left[\mathrm{Ca}^{2+}\right]_{i}$ may arise either from an increased rate of $\mathrm{Ca}^{2+}$ release from thapsigarginsensitive intracellular $\mathrm{Ca}^{2+}$ stores or from a decreased activity of sarco-endoplasmic reticulum-mediated $\mathrm{Ca}^{2+}$ uptake. The first possibility was tested by the addition of glucose to round spermatids in the absence of external $\mathrm{Ca}^{2+}$. After $\left[\mathrm{Ca}^{2+}\right]_{i}$ began to increase, thapsigargin was added. Activation by glucose metabolism of $\mathrm{Ca}^{2+}$ release pathways from intracellular $\mathrm{Ca}^{2+}$ stores (for an example, see Takasawa et al., 1993) was expected to produce a higher rate of increase in thapsigargin-induced $\left[\mathrm{Ca}^{2+}\right]_{i}$ in the presence rather than in the absence of glucose. No significant differences in the rates of thapsigargin-induced $\left[\mathrm{Ca}^{2+}\right]_{i}$ release in the absence and presence of glucose were found (paired experiments, $n=3$, not shown). Hence, the results of the present study are consistent with the contention that glucose-induced changes in $\left[\mathrm{Ca}^{2+}\right]_{i}$ can be attributed to glucose-induced changes in sarco-endoplasmic reticulum-ATPase transport activity in round spermatids. On average, glucose was able to induce the release of approximately $25 \%$ of thapsigargin-sensitive intracellular $\mathrm{Ca}^{2+}$ stores.

\section{Glycolytic metabolism and glucose-induced changes in $\left[\mathrm{Ca}^{2+}\right]_{i}$ in rat pachytene spermatocytes and round spermatids}

A transported but non-metabolizable analogue of glucose (3-O-methyl-D-glucopyranoside: OMG) and a transported and hexokinase-metabolizable analogue of glucose (2-deoxy glucose: DOG) were used to test whether glucose metabolism was needed for the glucose-induced increase in $\left[\mathrm{Ca}^{2+}\right]_{i}$ in spermatogenic cells. Addition of OMG $\left(5 \mathrm{mmol} \mathrm{I}^{-1}\right)$ did not produce a significant change in $\left[\mathrm{Ca}^{2+}\right]_{\mathrm{i}}$ in pachytene spermatocytes $\left(0.8 \pm 1.1 \mathrm{nmol} \mathrm{I}^{-1}, n=4\right)$ or round spermatids $\left(0.9 \pm 1.2 \mathrm{nmol} \mathrm{I}^{-1}, n=4\right)$ (Fig. 4a,b). In contrast, addition of DOG $\left(5 \mathrm{mmol} \mathrm{I}^{-1}\right)$ induced a clear increase in $\left[\mathrm{Ca}^{2+}\right]_{i}$ in both pachytene spermatocytes $\left(16 \pm 3 \mathrm{nmol} \mathrm{I}^{-1}, \quad n=6\right)$ and round spermatids (33 $\pm 11 \mathrm{nmol} \mathrm{I}^{-1}, n=5 ; P<0.01$ ). After the addition of DOG or OMG, thapsigargin (inhibitor of the intracellular $\mathrm{Ca}^{2+}-\mathrm{Mg}^{2+}$-ATPase) produced a large increase in $\left[\mathrm{Ca}^{2+}\right]_{\mathrm{i}}$ $\left(112 \pm 25 \mathrm{nmol} \mathrm{I}^{-1}, n=6\right)$ above the concentrations of $\left[\mathrm{Ca}^{2+}\right]_{\mathrm{i}}$ induced by the glucose analogues. This result shows that the $\mathrm{Ca}^{2+}$ content of intracellular $\mathrm{Ca}^{2+}$ stores was not limiting the response to OMG or DOG.

In round spermatids that were incubated with $5 \mathrm{mmol}$ L-lactate $\mathrm{I}^{-1}$, washed and treated with $1 \mathrm{mmol}$ iodoactetate (inhibitor of glyceraldehyde 3-P dehydrogenase, GPDH) $\mathrm{I}^{-1}$, the increase in $\left[\mathrm{Ca}^{2+}\right]_{i}$ after the addition of glucose was significantly augmented (Fig. 6a; $61 \pm 8 \mathrm{nmol} \mathrm{I}^{-1}$ versus $22 \pm 4 \mathrm{nmol} \mathrm{I}^{-1}, n=4, P<0.01$, paired test). In pachytene spermatocytes, and in the absence of iodoacetate, $\left[\mathrm{Ca}^{2+}\right]_{i}$ reached a maximum after the addition of glucose and then slowly decreased toward basal amounts. This phase of decreasing $\left[\mathrm{Ca}^{2+}\right]_{i}$ seemed to be related to the metabolism of glucose beyond GPDH in spermatocytes, as it was abolished by treatment with iodoacetate (Fig. 6b).

\section{Effects of glucose on adenine nucleotide pools in round spermatids}

As shown above, glycolytic metabolism and specifically sugar phosphorylation appear to be essential for the glucose induction of $\left[\mathrm{Ca}^{2+}\right]_{i}$ changes in pachytene spermatocytes and round spermatids. Hence, either intermediaries of glucose metabolism or changes in adenine nucleotide pools 

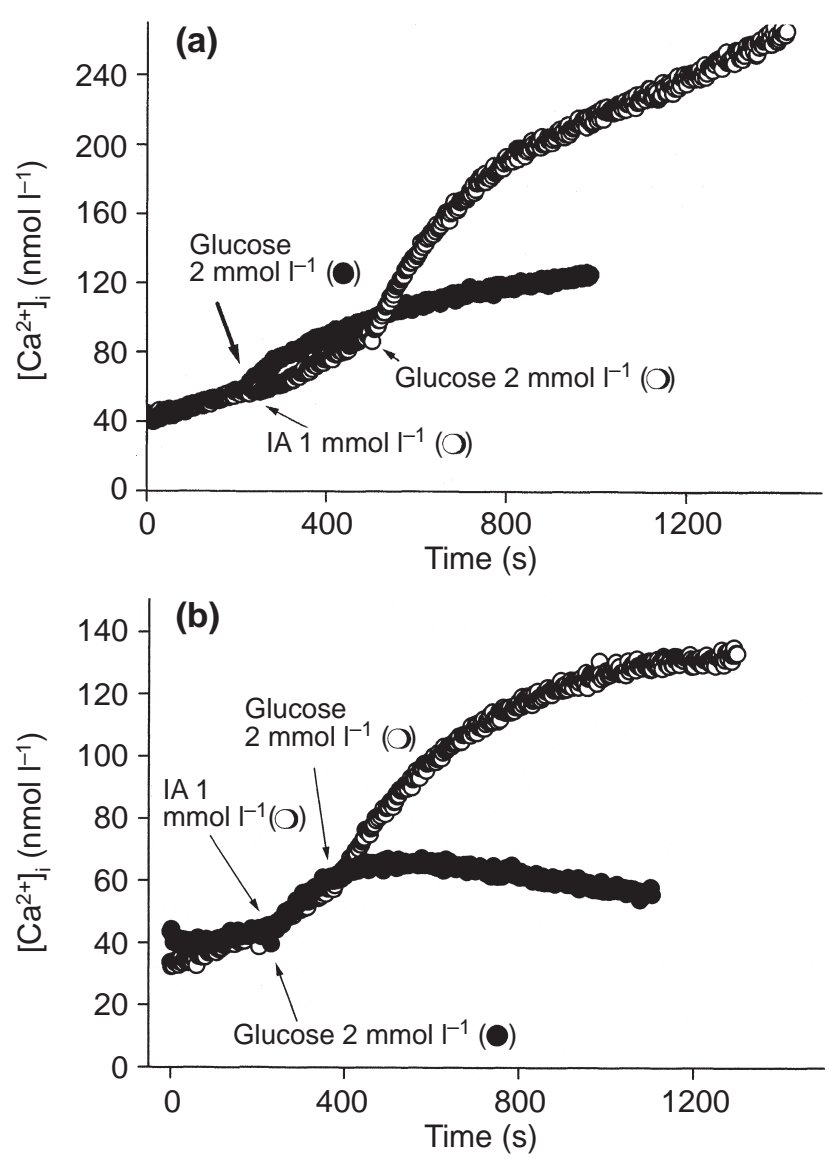

Fig. 6. Intracellular $\left[\mathrm{Ca}^{2+}\right]$ of (a) round spermatids and (b) pachytene spermatocytes of rats loaded with fura-2. The measurements were made in a spectrofluorometer at $33^{\circ} \mathrm{C}$ in $140.0 \mathrm{mmol}$ $\mathrm{Na}^{+} \mathrm{I}^{-1}, 4.6 \mathrm{mmol} \mathrm{K} \mathrm{I}^{-1}, 1.6 \mathrm{mmol} \mathrm{Mg}^{2+} \mathrm{I}^{-1}, 1.6 \mathrm{mmol}$ phosphate $\mathrm{I}^{-1}, 0.5 \mathrm{mmol} \mathrm{Ca}^{2+} \mathrm{I}^{-1}, 10 \mathrm{mmol}$ Hepes $\mathrm{I}^{-1}, \mathrm{pH} 7.4(\mathrm{KH})$ buffer with $0.5 \mathrm{mmol}$ EGTA $\mathrm{I}^{-1}$. The cells were incubated previously for $20 \mathrm{~min}$ in $\mathrm{KH}, 24 \mathrm{mmol}$ bicarbonate $\mathrm{I}^{-1}$ (KHB) and $5 \mathrm{mmol}$ L-lactate (KHB-lactate) in a $95 \% \mathrm{O}_{2}$ and $5 \% \mathrm{CO}_{2}$ atmosphere, washed in $\mathrm{KH}-\mathrm{EGTA}$ medium and added to the fluorometer cuvette. At the indicated times (arrows), glucose alone $(0)$ or iodoacetate (IA) followed by glucose $(O)$ were added to the curvette. These measurements were representative of experiments performed in three different cell preparations.

(Nakamura et al., 1982; Grotegoed et al., 1986; Reyes et al., 1990) could be involved in the glucose-induced modulation of $\mathrm{Ca}^{2+}$ uptake by intracellular $\mathrm{Ca}^{2+}$ stores. Two approaches were used to test the possibility that glucose metabolism could trigger rapid changes in adenine nucleotide pools. Firstly, in conditions of abundant $\mathrm{O}_{2}$, inorganic phosphate and reducing equivalent supply to the mitochondria, these organelles should respond with changes in $\mathrm{O}_{2}$ consumption to changes in the concentrations of cytosolic ADP. In agreement with the predicted changes in adenine nucleotides induced by activation of glycolysis, addition of glucose in the presence of $1 \mathrm{mmol} \mathrm{L}-$ lactate $\mathrm{I}^{-1}$ induced a transient increase in $Q_{2}(21 \%$
Table 1. Relative adenine nucleotide content in rat round spermatids in the presence of glucose

\begin{tabular}{lccc}
\hline Time $(\min )$ & {$[\mathrm{ATP}]$} & {$[\mathrm{ADP}]$} & {$[\mathrm{AMP}]$} \\
\hline 0 & 1.00 & 1.00 & 1.00 \\
0.5 & $0.90 \pm 0.09$ & $1.02 \pm 0.16$ & $0.86 \pm 0.24$ \\
2.0 & $1.25 \pm 0.48$ & $1.00 \pm 0.19$ & $0.83 \pm 0.20$ \\
4.0 & $0.82 \pm 0.35$ & $1.31 \pm 0.08^{*}$ & $1.89 \pm 0.10^{*}$ \\
\hline
\end{tabular}

Round spermatids were incubated previously in a shaker waterbath in $140.0 \mathrm{mmol} \mathrm{Na}{ }^{-1}, 4.6 \mathrm{mmol} \mathrm{K}{ }^{+}{ }^{-1}, 1.6 \mathrm{mmol} \mathrm{Mg}{ }^{2+} \mathrm{I}^{-1}, 1.6 \mathrm{mmol}$ phosphate $\mathrm{I}^{-1}, 0.5 \mathrm{mmol} \mathrm{Ca}^{2+} \mathrm{I}^{-1}, 10 \mathrm{mmol}$ Hepes $\mathrm{I}^{-1}, \mathrm{pH} 7.4(\mathrm{KH})$, $24 \mathrm{mmol}$ bicarbonate (KHB) $\mathrm{I}^{-1}$ and $5 \mathrm{mmol}^{-}$-lactate $\mathrm{I}^{-1}$ (KHB-lactate) under an atmosphere of $95 \% \mathrm{O}_{2}$ and $5 \% \mathrm{CO}_{2}$ at $33^{\circ} \mathrm{C}$. The spermatids were subsequently washed in a medium devoid of substrates. Samples were taken at time 0 and glucose $\left(5 \mathrm{mmol} \mathrm{I}^{-1}\right)$ was added at 0.5, 2.0 and $4.0 \mathrm{~min}$. ATP, $\mathrm{ADP}$ and $\mathrm{AMP}$ are expressed as the ratio between the concentrations per $\mathrm{mg}$ of cell protein at the indicated times and the concentrations at time 0 . The measurements were performed in three cell preparations. Results are expressed as the mean $\pm \mathrm{SD}$. ${ }^{*}$ Significantly different (paired test, $P<0.01$ ) from the values at time 0 .

average, range $15-35 \%, n=4)$ in round spermatids. This glucose-induced increase in $\mathrm{QO}_{2}$ indicates that glucose metabolism induced a transient burst of ADP followed by a new lower steady-state level of this nucleotide. Secondly, HPLC determinations were used to estimate the amounts of ATP, ADP and AMP at short intervals after the addition of glucose to a suspension of round spermatid cells. Intracellular ATP concentrations did not change significantly at $4 \mathrm{~min}$ after glucose was added to round spermatids (Table 1). As a comparison, the addition of antimycin (inhibitor of the mitochondrial electron chain) induced a decrease to $10 \%$ of the original concentrations of ATP in round spermatids in a similar time (Herrera et al., 2000). However, intracellular ADP and AMP concentrations did show a significant increase at $4 \mathrm{~min}$ after addition of glucose to the cells, indicating an increased turnover of ATP in round spermatids in the presence of glucose. However, it should be noted that as a result of the relatively large variance and the averaging character of nucleotide measurements by HPLC, this method would fail to detect small or localized changes in nucleotide pools in the cells.

\section{Intracellular $\mathrm{Ca}^{2+}$ content of round spermatids and changes in the external lactate and g/ucose concentrations}

It is well known that Sertoli cells respond to FSH, catecholamines and cytokines with an increase in their glycolytic flux and lactate output (Mita et al., 1982; Le Gac et al., 1983; Hall and Mita, 1984; Riera et al., 2001). FSH pulses in male mammals have a periodicity of approximately 2-3 h (Pincus et al., 1997). Hence, it is expected that the glycolytic activity of Sertoli cells and their release of lactate and glucose to the seminiferous tubule adluminal micro-environment would vary according to the endocrine and paracrine status of these cells. The putative dynamics of 
(a)

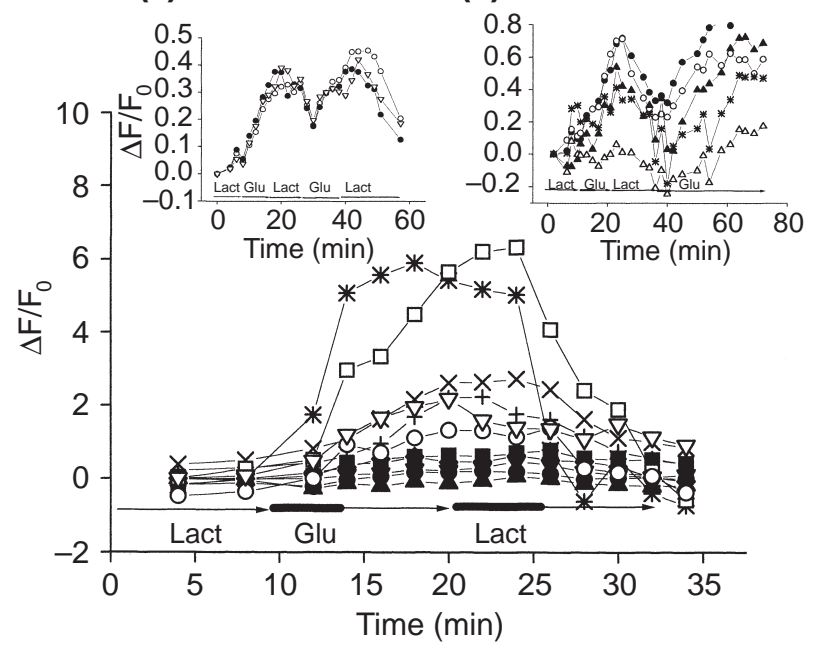

Fig. 7. Relative fluorescence of fluo-3-loaded single cells obtained from fluorometric imaging at $33^{\circ} \mathrm{C} . \mathrm{F}_{0}$ is the fluorescence of each cell at time zero. The cells were perfused with $140.0 \mathrm{mmol}$ $\mathrm{Na}^{+} \mathrm{I}^{-1}, 4.6 \mathrm{mmol} \mathrm{K} \mathrm{I}^{-1}, 1.6 \mathrm{mmol} \mathrm{Mg}^{2+} \mathrm{I}^{-1}, 1.6 \mathrm{mmol}$ phosphate $\mathrm{I}^{-1}, 0.5 \mathrm{mmol} \mathrm{Ca}{ }^{2+} \mathrm{I}^{-1}, 10 \mathrm{mmol}$ Hepes $\mathrm{I}^{-1}, \mathrm{pH} 7.4(\mathrm{KH})$-EGTA and 5 mmol L-lactate $\mathrm{I}^{-1}$ or $5 \mathrm{mmol}$ glucose solution $\mathrm{I}^{-1}$ as indicated on the bottom lines. Heavy lines indicate the time taken for complete changes in the solutions bathing the cells. The data shown are from experiments performed in three different cell preparations. Inserts show measurements performed in similar conditions but with two cycles of glucose and L-lactate solution changes (insert, a) or with changes in glucose and L-lactate solutions followed by glucose solution maintained until the end of the experiment (insert, b). Lact: lactose; glu: glucose.

glucose and lactate concentrations in the spermatogenic cell extracellular environment in the seminiferous tubule were mimicked by varying the external lactate and glucose concentrations by passing solutions containing lactate or glucose on single round spermatids. Round spermatid $\left[\mathrm{Ca}^{2+}\right]_{i}$ followed the pulses in lactate and glucose with changes in $\left[\mathrm{Ca}^{2+}\right]_{i}$, setting a pattern of pulsed changes in $\left[\mathrm{Ca}^{2+}\right]_{\mathrm{i}}$ (Fig. 7). Approximately $80 \%$ of the cells responded to glucose with changes in fluo-3 fluorescence of $>20 \%$. However, the magnitude of the response was clearly heterogeneous. As our method of vital cell identification does not allow sub-classification of rat spermatids at these stages of development, it was not possible to ascribe this diversity of glucose sensitivities in round spermatids $\left[\mathrm{Ca}^{2+}\right]_{\mathrm{i}}$ unequivocally to a differentiation-related phenomenon.

\section{Glucose-induced changes in $\mathrm{pH}_{i}$ and their relation to $\left[\mathrm{Ca}^{2+}\right]_{i}$ changes}

The addition of glucose to round spermatids and pachytene spermatocytes induced a decrease in $\mathrm{pH}_{\mathrm{i}}$ of approximately $0.5 \mathrm{pH}$ units (Fig. 8). There was a delay in these changes in $\mathrm{pH}_{\mathrm{i}}$ (measured from the time of glucose addition to the extrapolated initial velocity of $\mathrm{pH}_{\mathrm{i}}$ change)

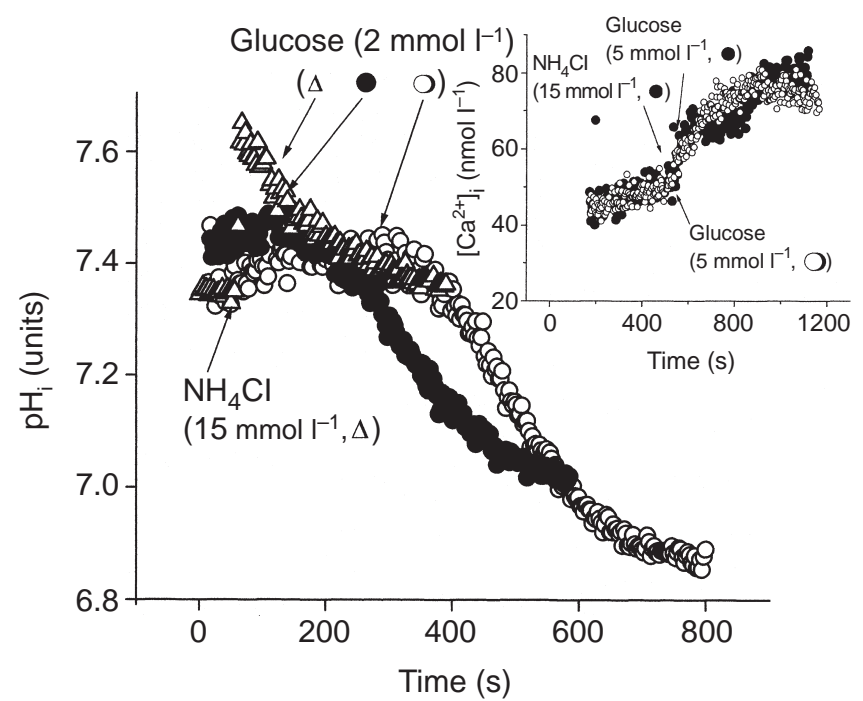

Fig. 8. Intracellular $\mathrm{pH}$ of pachytene spermatocytes (-) and round spermatids $(O, \triangle)$ of rats. The cells were incubated previously in $140.0 \mathrm{mmol} \mathrm{Na}^{+} \mathrm{I}^{-1}, 4.6 \mathrm{mmol} \mathrm{K}^{+} \mathrm{I}^{-1}, 1.6 \mathrm{mmol} \mathrm{Mg}{ }^{2+}$

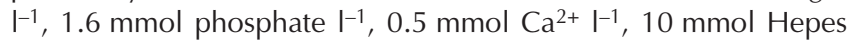
$\mathrm{I}^{-1}, \mathrm{pH} 7.4(\mathrm{KH}), 24 \mathrm{mmol}$ bicarbonate $\mathrm{I}^{-1}(\mathrm{KHB})$ and $5 \mathrm{mmol}$ L-lactate (KHB-lactate) under a $95 \% \mathrm{O}_{2}$ and $5 \% \mathrm{CO}_{2}$ atmosphere, and subsequently washed three times in $\mathrm{KH}$ medium without substrates. The measurements were performed at $33^{\circ} \mathrm{C}$ with constant stirring. At the indicated times (arrows), $2 \mathrm{mmol}$ glucose $\mathrm{I}^{-1}$ was added to the cell suspension. $\mathrm{NH}_{4} \mathrm{Cl}\left(15 \mathrm{mmol} \mathrm{I}^{-1}, \triangle\right)$ was added to show that the glucose-induced decrease in $\mathrm{pH}$ below 7.3 was prevented by $\mathrm{NH}_{4} \mathrm{Cl}$. These measurements are representative of experiments performed in three different cell preparations. Intracellular $\left[\mathrm{Ca}^{2+}\right]$ of rat round spermatids loaded with fura-2 (insert). The measurements were made in a spectrofluorometer at $33^{\circ} \mathrm{C}$ in $\mathrm{KH}$ buffer with $0.5 \mathrm{mmol}$ EGTA ${ }^{-1}$. $\mathrm{NH}_{4} \mathrm{Cl}\left(15 \mathrm{mmol} \mathrm{I}^{-1}\right.$, -) was added before addition of glucose to the cells.

of $56 \pm 28 \mathrm{~s}(n=7)$ in round spermatids and $42 \pm 14 \mathrm{~s}$ $(n=7)$ in pachytene spermatocytes. In contrast, the changes in $\left[\mathrm{Ca}^{2+}\right]_{\mathrm{i}}$ in these cells were initiated approximately $10 \mathrm{~s}$ after glucose addition. These results provide a kinetic argument to state that $\left[\mathrm{Ca}^{2+}\right]_{i}$ changes induced by glucose did not derive from changes in $\mathrm{pH}_{\mathrm{i}}$ in round spermatids or pachytene spermatocytes. Furthermore, the addition of $\mathrm{NH}_{4} \mathrm{Cl}$, which increased $\mathrm{pH}_{\mathrm{i}}$ in these cells and prevented the decrease in $\mathrm{pH}$ induced by glucose (Fig. 8), did not modify the kinetics or the magnitude of the changes in $\left[\mathrm{Ca}^{2+}\right]_{\mathrm{i}}$ induced by glucose (Fig. 8, insert).

\section{Discussion}

There is extensive experimental evidence supporting the idea that glucose and lactate concentrations are regulated by the glycolytic activity of Sertoli cells in the microenvironment surrounding meiotic and post-meiotic spermatogenic cells (Robinson and Fritz, 1981; Mita et al., 1982; Le Gac et al., 1983; Hall and Mita, 1984). FSH, catecholamines and cytokines increase the glycolytic activity of 
Sertoli cells (Mita et al., 1982; Le Gac et al., 1983; Hall and Mita, 1984; Riera et al., 2001) indicating an endo-paracrine modulation of glucose and lactate release and changes of the concentrations of these substrates in the adluminal compartment of the seminiferous tubules. The results of the present study demonstrating that changes in extracellular glucose and lactate concentrations can induce a dynamic behaviour of $\left[\mathrm{Ca}^{2+}\right]_{i}$ in meiotic and post-meiotic spermatogenic cells provide a hypothetical link between endoparacrine status in the seminiferous tubules, the functional state of Sertoli cells and intracellular signalling in spermatogenic cells.

The lack of a significant difference in the glucoseinduced increase in $\left[\mathrm{Ca}^{2+}\right]_{i}$ in the presence and absence of external $\mathrm{Ca}^{2+}$ does not support an important role for $\mathrm{Ca}^{2+}$ entry in the glucose-induced $\left[\mathrm{Ca}^{2+}\right]_{i}$ changes in meiotic and post-meiotic spermatogenic cells. The results of the present study indicate that most of the cytosolic $\left[\mathrm{Ca}^{2+}\right]$ increase induced by glucose came from thapsigargin-sensitive intracellular $\mathrm{Ca}^{2+}$ stores. Furthermore, glucose was able to inhibit sarco-endoplasmic reticulum ATPase $\mathrm{Ca}^{2+}$ uptake by intracellular $\mathrm{Ca}^{2+}$ stores in round spermatids, and this effect was not mediated by changes in intracellular $\mathrm{pH}$. Nucleotide turnover could be involved in this phenomenon.

Both kinetically and in magnitude, the $\left[\mathrm{Ca}^{2+}\right]_{i}$ of pachytene spermatocytes and round spermatids responded in different ways to the addition of glucose. In the presence of lactate, $\left[\mathrm{Ca}^{2+}\right]_{i}$ in round spermatids correlates with the concentration ratios of lactate and glucose. Thus, a differential and developmentally expressed intracellular $\mathrm{Ca}^{2+}$ sensitivity to glucose and lactate was demonstrated in postmeiotic spermatogenic cells. The metabolism of glucose was necessary to observe the effects of glucose on $\left[\mathrm{Ca}^{2+}\right]_{i}$ in both pachytene spermatocytes and round spermatids, as no effect of a non-metabolizable glucose analogue (OMG) was observed. The effects of 2-deoxy glucose and the enhancement of the increase in $\left[\mathrm{Ca}^{2+}\right]_{\mathrm{i}}$ induced by glucose after inhibition of GPDH with iodoacetate indicate that glucose phosphorylation is an essential mechanism involved in the glucose-dependent changes in $\left[\mathrm{Ca}^{2+}\right]_{i}$. Glucose metabolism can induce a net ATP hydrolysis in spermatids after several minutes of exposure of the cells to this sugar, apparently by sugar phosphorylation and activation of a substrate cycle catalysed by phosphofructokinase and fructose 1,6 bisphosphatase (Nakamura et al., 1982; Grotegoed et al., 1986; Reyes at al., 1990). A decrease in intracellular [ATP] was not observed $4 \mathrm{~min}$ after exposure of round spermatids to glucose. However, intracellular [ADP] and [AMP] were significantly increased at this time. These changes in intracellular adenine nucleotides and the rapid changes in $\mathrm{QO}_{2}$ induced by glucose demonstrate a glucose-stimulated rapid increase in ATP turnover in round spermatids. These results strongly indicate that the ATP consuming steps in glycolysis and a likely limiting flux in $\mathrm{GPDH}$ in round spermatids (for an example, see Nakamura et al., 1982) can be responsible for the differential response to glucose in round spermatids. The idea that addition of glucose could increase $\left[\mathrm{Ca}^{2+}\right]_{i}$ in round spermatids by increasing the turnover of ATP is in agreement with previous findings that inhibition of mitochondrial metabolism, which induced rapid changes in intracellular adenine nucleotides, also rapidly induced an increase in $\left[\mathrm{Ca}^{2+}\right]_{i}$ in these cells (Herrera et al., 2000). The transient increase in $\left[\mathrm{Ca}^{2+}\right]_{\mathrm{i}}$ induced by glucose in pachytene spermatocytes could be thought to arise from the fact that these cells have a larger glycolytic flux (as compared with round spermatids) leading to pyruvate and lactate production that, in turn, would be able to enter oxidative metabolism (Bajpai et al., 1998). Thus, these cells would present a transient glucose phosphorylation (increased ATP turnover) followed by a relatively larger (as compared with round spermatids) flux through ATP generating steps in glycolysis and oxidative phosphorylation.

In light of the results of the present study, the metabolic properties of post-meiotic cells emerge as a differentiationrelated process that causes $\left[\mathrm{Ca}^{2+}\right]_{i}$ of post-meiotic cells to be more responsive to the external supply of oxidative and glycolytic substrates. Local pulses of cytokines or catecholamines, or cyclic FSH (for example, Pincus et al., 1997) could translate to changes in glycolytic fluxes in Sertoli cells and a dynamic (but inverse) supply of glucose and lactate to meiotic and post-meiotic spermatogenic cells. In the present study it was shown that steady-state or cyclic changes in lactate and glucose can produce a dynamic of $\left[\mathrm{Ca}^{2+}\right]_{i}$ composed of sustained or oscillatory changes. These dynamics of intracellular $\mathrm{Ca}^{2+}$ are presently considered to form the basis for intracellular $\mathrm{Ca}^{2+}$ signalling in most cells (Berridge et al., 2000). Thus, the present study provides a physiological interpretation for the differentiation-related changes in carbohydrate metabolism in spermatogenic cells, linking Sertoli cell metabolism, their endocrine and paracrine control, and intracellular signalling in spermatogenic cells. Along these lines, major aspects of this working hypothesis to be determined would be whether there is a dynamic secretion of glucose and lactate in the seminiferous tubules, whether these changes can induce $\left[\mathrm{Ca}^{2+}\right]_{\mathrm{i}}$ changes in spermatogenic cells in situ and, finally, how these $\left[\mathrm{Ca}^{2+}\right]_{\mathrm{i}}$ changes could affect growth and differentiation of spermatogenic cells.

The authors thank I. Qinones and C. Guy for their superb editorial assistance, and L. Alvarez for excellent laboratory assistance. Financed by Fondecyt 1990689 and DGIP/UCV.

\section{References}

Angulo C, Rauch MC, Droppelmann A, Reyes AM, Slebe JC, DelgadoLopez F, Guaiquil VH, Vera JC and Concha II (1998) Hexose transporter expression and function in mammalian spermatozoa: cellular localisation and transport of hexoses and vitamin C Journal of Cellular Biochemistry 71 189-203

Bajpai M, Gupta G and Setty BS (1998) Changes in carbohydrate metabolism of testicular germ cells during meiosis in the rat European Journal of Endocrinology 138 322-327

Berridge MJ, Lipp P and Bootman MD (2000) The versatility and 
universality of calcium signalling Nature Reviews in Molecular and Cell Biology $111-21$

Berrios J, Osses N, Opazo C, Arenas G, Mercado L, Benos DJ and Reyes JG (1998) Intracellular $\mathrm{Ca}^{2+}$ homeostasis in rat round spermatids Biology of the Cell 90 391-398

Grootegoed JA, Jansen R and van der Molen HJ (1984) The role of glucose, pyruvate and lactate in ATP production by rat spermatocytes and spermatids Biochimica et Biophysica Acta 767 248-256

Grootegoed JA, Jansen R and van der Molen HJ (1986) Effect of glucose on ATP dephosphorylation in rat spermatids Journal of Reproduction and Fertility 77 99-107

Grynkiewicz G, Poenie M and Tsien RY (1985) A new generation of $\mathrm{Ca}^{2+}$ indicators with greatly improved fluorescence properties Journal of Biological Chemistry $2603440-3450$

Hall PF and Mita M (1984) Influence of follicle-stimulating hormone on glucose transport by cultured Sertoli cells Biology of Reproduction 31 863-869

Herrera E, Salas K, Lagos N, Benos DJ and Reyes JG (2000) Energy metabolism and its linkage to intracellular $\mathrm{Ca}^{2+}$ and $\mathrm{pH}$ regulation in rat spermatogenic cells Biology of the Cell 92 429-440

Jegou B (1993) The Sertoli-germ cell communications network in mammals International Reviews of Cytology 147 25-96

Larsson D, Larsson B, Lundgren T and Sundell K (1999) The effect of pH and temperature on the dissociation constant for fura-2 and their effects on $\left[\mathrm{Ca}^{2+}\right]_{\mathrm{i}}$ in enterocytes from a poikilothermic animal, Atlantic cod (Gadus morhua). Analytical Biochemistry 273 60-65

Le Gac F, Attramadal M, Borrebaek B, Horn R, Froysa A, Tvermyr M and Hansson V (1983) Effects of FSH, isoproterenol and cyclic AMP on the production of lactate and pyruvate by cultured Sertoli cells Archives of Andrology 10 149-154

Mita M, Price J and Hall PF (1982) Stimulation by FSH of synthesis of lactate by Sertoli cells from rat testis Endocrinology 110 1535-1541

Nakamura M, Fujiwara A, Yasumasu I, Okinaga S and Arai K (1982) Regulation of glucose metabolism by adenine nucleotides in round spermatids from rat testis Journal of Biological Chemistry 257 13 945-13 950

Nakamura M, Yamaguchi K, Suzuki A, Okinaga S and Arai K (1986) Metabolism of round spermatids: a possible regulation of hexose transport Development, Growth and Differentiation 28 499-504
Pincus SM, Veldhuis JD, Mulligan T, Iranmanesh A and Evans WS (1997) Effects of age on the irregularity of $\mathrm{LH}$ and $\mathrm{FSH}$ serum concentrations in women and men American Journal of Physiology 273 E989-E995

Pizzo P, Fasolato C and Pozzan T (1997) Dynamic properties of an inositol 1,4,5-trisphosphate- and thapsigargin-insensitive calcium pool in mammalian cell lines Journal of Cell Biology 136 355-366

Reyes JG, Velarde MV, Ugarte R and Benos DJ (1990) The glycolytic component of rat spermatid energy and acid-base metabolism American Journal of Physiology 259 C660-C667

Reyes JG, Diaz A, Osses N, Opazo C and Benos DJ (1997) On stage single cell identification of rat spermatogenic cells Biology of the Cell 89 1-10

Riera MF, Meroni SB, Gomez GE, Schteingart HG, Pellizzari EH and Cigorraga SB (2001) Regulation of lactate production by FSH, IL1- $\beta$ and TNF- $\alpha$ in rat Sertoli cells General and Comparative Endocrinology 122 88-97

Rink TJ, Tsien RY and Pozzan T (1982) Cytoplasmic $\mathrm{pH}$ and free $\mathrm{Mg}^{++}$in lymphocytes Journal of Cell Biology 95 189-196

Robinson R and Fritz IB (1981) Metabolism of glucose by Sertoli cells in culture Biology of Reproduction 24 1032-1041

Romrell LJ, Bellvé AR and Fawcett DW (1976) Separation of mouse spermatogenic cells by sedimentation velocity Developmental Biology 19119-131

Takasawa S, Nata K, Yonekura H and Okamoto H (1993) Cyclic ADPribose in insulin secretion from pancreatic beta cells Science 259 370-373

Treviño CL, Santi CM, Beltran C, Hernandez-Cruz A, Darszon A and Lomeli $\mathbf{H}$ (1998) Localisation of $\mathrm{IP}_{3}$ and ryanodine receptors during mouse spermatogenesis: possible functional implications Zygote $\mathbf{6}$ 159-172

Turner TT, D'Addario DA and Howards SS (1983) The transepithelial

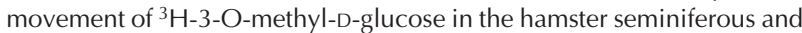
caudal epididymal tubules Fertility and Sterility 40 530-535

Received 30 July 2001.

First decision 8 October 2001.

Revised manuscript received 11 December 2001.

Accepted 14 January 2002. 